\title{
Comprehending customer satisfaction with hotels
}

\section{Data analysis of consumer-generated reviews}

\author{
Hongxiu Li \\ Department of Information and Knowledge Management, Tampere University, \\ Tampere, Finland \\ Yong Liu \\ School of Economics, Aalto University, Helsinki, Finland \\ Chee-Wee Tan \\ Department of Digitalization, Copenhagen Business School, \\ Frederiksberg, Denmark, and \\ Feng $\mathrm{Hu}$ \\ Xingzhi College, Zhejiang Normal University, Jinhua, China
}

Received 25 June 2019 Revised 11 October 2019 18 January 2020 Accepted 20 January 2020

\begin{abstract}
Purpose - Building on the three-factor theory, this study aims to unravel how the role of hotel attributes such as basic, excitement and performance factors could differ in accordance with different hotel star ratings and distinct customer segments.

Design/methodology/approach - This study explores the asymmetric effects of hotel attributes on customer satisfaction by extracting 412,784 consumer-generated reviews from TripAdvisor across different cities in China.

Findings - By taking into account the origins of customers and hotel star ratings, the study uncovers that guests' expectations of hotel performance differ with respect to their origins (domestic and international guests) and the star ratings of the hotels being reviewed, thereby moderating the asymmetric impact of hotel attributes on customer satisfaction.

Research limitations/implications - The study compares and contrasts the determinants of customer satisfaction for domestic and international guests in the context of Chinese hotels. Care should still be exercised when generalizing the insights gleaned from this study to other contexts.

Practical implications - The findings from this study translate into actionable guidelines for hotel operators to make informed decisions regarding service improvement.

Originality/value - The study extends previous work by offering a deeper understanding of the asymmetric impact of hotel attributes on customer satisfaction. Specifically, this study provides a deep understanding of the different hotel attributes such as basic, performance and excitement factors in explaining customer satisfaction among different hotel customer segments. Findings from this study can not only inform hotel operators on the significance of various hotel attributes in determining customer satisfaction but also guide the formulation of business strategies to retain customers by inducing delight and not frustration.
\end{abstract}

Keywords Customer satisfaction, Three-factor theory, Hotel management, Consumer-generated review

Paper type Research paper

(C) Hongxiu Li, Yong Liu, Chee-Wee Tan and Feng Hu. Published by Emerald Publishing Limited. This article is published under the Creative Commons Attribution (CC BY 4.0) licence. Anyone may reproduce, distribute, translate and create derivative works of this article (for both commercial and non-commercial purposes), subject to full attribution to the original publication and authors. The full terms of this licence may be seen at http://creativecommons.org/licences/by/4.0/legalcode

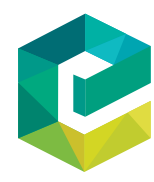

International Journal of Contemporary Hospitality Management Vol. 32 No. 5,2020 pp. $1713-1735$
Emerald Publishing Limited 0959-6119 DOI 10.1108/IJCHM-06-2019-0581 
$\mathrm{IJCHM}$

32,5

1714

\section{Introduction}

It is natural for hotel operators to invest a tremendous amount of resources in satisfying their customers. As customer satisfaction constitutes a critical barometer for assessing hotel performance, an in-depth appreciation of the factors contributing to both satisfied and dissatisfied customers is paramount to hotel management. On one hand, very satisfied (or delighted) customers are more likely to return and recommend a hotel. Delighted customers exhibit behavioral patterns that are distinct from moderately satisfied customers. On the other hand, very dissatisfied (or frustrated) customers are likely to spread negative word of mouth that not only tarnishes the image and reputation of the targeted hotel but also decreases hotel revenue by deterring potential customers. Indeed, it has been documented that one negative review from an unhappy customer can translate into the subsequent loss of 30 customers (Olsen, 2010).

The above phenomena highlight the urgency for modern hospitality industries to strive for customer delight while averting customer frustration. Yet, it should not come as a surprise that hotel operators have to pursue separate business strategies to attain the two business objectives. Past studies have demonstrated that the determinants of customer delight are distinguishable from those that cause customer frustration (Albayrak and Caber, 2013; Alegre and Garau, 2011; Füller and Matzler, 2008). For instance, while hotel guests may be indifferent to having a clean towel, they are likely to be irritated by the presence of a dirty towel. Conversely, an offering of welcome chocolate in the room may delight customers, even though customers are unlikely to be unhappy in the absence of such services. Conceivably, hotel attributes could exert asymmetric impact on customer satisfaction: whereas customers can be highly satisfied with a hotel attribute, they can be equally dissatisfied with another hotel attribute (Albayrak and Caber, 2015). In other words, the relationships between hotel attributes and customer satisfaction could be asymmetric. Specifically, one unit of positive performance of a hotel attribute could have a much greater impact on customer satisfaction than a corresponding unit of negative performance, and similarly negative performance of a hotel attribute could outweigh the effect of its positive performance on customer satisfaction.

The three-factor theory holds that product/service attributes exert asymmetric effects on overall customer satisfaction. According to the three-factor theory (Kano et al., 1984), hotel attributes can be categorized into basic, performance and excitement factors, where basic and excitement factors denote dissatisfiers and satisfiers, respectively, and performance factors induce satisfaction and dissatisfaction in a linear and symmetric fashion.

Although prior research has hinted at asymmetric relationships between product/service attributes and overall customer satisfaction, their symmetric relationships continue to be a prime focus of extant literature on customer satisfaction (Möhlmann, 2015; Yang et al., 2018). Despite alluding to the symmetric relationships between product/service attributes and customer satisfaction, past studies have largely ignored the importance of those attributes that unilaterally lead to customer dissatisfaction or satisfaction. Additionally, even as a handful of studies that have attested to the existence of asymmetric relationships between product/service attributes and overall customer satisfaction in hospitality industry, there has been little research that systematically categorizes hotel attributes in accordance with the three-factor theory (Albayrak and Caber, 2013; Alegre and Garau, 2011; Füller and Matzler, 2008). Consequently, there is a dearth of research that explores the asymmetric effects of hotel attributes on overall customer satisfaction in the hospitality sector, especially those attributes corresponding to:

- basic factors, the absence of which culminates in dissatisfaction;

- excitement factors, the presence of which leads to satisfaction; and

- performance factors, which exert a symmetric and linear influence on satisfaction. 
Furthermore, even though domestic guests, as compared to their international counterparts, may develop different expectations on the performance of hotels with different star ratings, little is known as to whether hotel star rating moderates the asymmetric effects of hotel attributes on customer satisfaction among different customer segments, such as domestic and international guests.

To bridge the abovementioned knowledge gaps, we draw on the three-factor theory to unravel the determinants of customer satisfaction and dissatisfaction via data analysis based on a large amount of online hotel reviews. Having been applied in past studies to uncover determinants of customer satisfaction and dissatisfaction across diverse contexts, the three-factor theory offers a solid theoretical framework for comprehending customer satisfaction and dissatisfaction by taking into account the asymmetric impact of hotel attributes on customers' assessment of hotel performance (Albayrak and Caber, 2015; Füller and Matzler, 2008; Matzler and Renzl, 2007; Mikulic and Prebezac, 2012). Building on the three-factor theory, this study aims to unravel how the role of hotel attributes as basic, excitement and performance factors could differ in accordance with different hotel star ratings and distinct customer segments. Because star rating captures the ranking of hotels based on quality dimensions in the likes of price, facilities and level of service (Cser and Ohuchi, 2008), it is conceivable that customers would expect more from a hotel with high star rating than one with low star rating. Furthermore, we argue that domestic customers may expect different levels of performance in comparison to the international counterparts. By exploring the moderating influence of hotel star ratings and customer segments (domestic and international guests) on satisfaction and dissatisfaction, we endeavor to generate novel insights into the application of the three-factor theory in the context of hospitality industry. To this end, we not only turn to the three-factor theory to unravel determinants of customer satisfaction based on online hotel reviews but also examine whether these determinants vary for domestic versus international guests and for hotels with different star ratings.

To accomplish our research objectives, we extracted a sizeable amount of customer reviews from TripAdvisor to validate the three-factor theory through varying customer segments and hotel star ratings. Our study extends previous work by offering a deeper understanding of the asymmetric impact of hotel attributes on customer satisfaction. Findings from this study can not only inform hotel operators on the significance of various hotel attributes in determining customer satisfaction but also guide the formulation of business strategies to retain customers by inducing delight and not frustration.

The remainder of the paper is structured as follows. In Section 2, we review extant literature on the asymmetric effects of factors governing customer satisfaction and on customer satisfaction in the hospitality sector. Section 3 describes our methodology before presenting the results from our data analysis. Section 4 concludes with a discussion on the implications of our empirical findings for both theory and practice.

\section{Theoretical foundation}

Customer satisfaction/dissatisfaction is a dominant research stream within extant literature and has attracted scholarly attention across multiple disciplines. Although there is no general consensus on the definition for customer satisfaction and dissatisfaction, but consistent with the expectation disconfirmation theory (Oliver, 1977, 1980), we conceive customer satisfaction as originating from the comparison between a priori expectations and a posteriori perceived performance of a product or service (Oliver, 1977, 1980). If perceived performance is greater than expectations, positive disconfirmation and satisfaction will manifest. In contrast, the lower-than-expected performance of a product or service will

\section{Customer satisfaction with hotels}

1715 
IJCHM 32,5

culminate in negative disconfirmation and dissatisfaction. Confirmation or positive disconfirmation thus culminates in satisfaction, whereas negative disconfirmation leads to dissatisfaction. In this sense, both satisfaction and dissatisfaction can be characterized by the direction and degree of disparity between customer expectations and perceived performance of a product or service (Anderson, 1973). Such conceptions also resonate with past studies that deem satisfaction and dissatisfaction to be two sides of the same coin; satisfaction can be regarded as the opposite of dissatisfaction and vice versa (Herzberg, 1959; Ou and Sia, 2010). In other words, we adhere to Herzberg's (1959) theorization of dissatisfaction as that of low satisfaction.

Yet, prior research has alleged to the asymmetric impacts of customer satisfaction and dissatisfaction on consumer behavior, despite their being two ends of a spectrum. As contended by Chen et al. (2014), it is imperative to consider both satisfaction and dissatisfaction when investigating consumer behavior (e.g. loyalty) because dissatisfaction is qualitatively distinct from satisfaction. Likewise, Ou and Sia (2010) have advocated for the simultaneous inclusion of both satisfaction and dissatisfaction when researching online consumer behavior because of the latter's complexity. In line with the prospect theory (PT) (Kahneman and Tversky, 1979), dissatisfaction might exert a stronger negative impact on consumer behavior than that of degraded satisfaction. Insofar as dissatisfaction is distinguishable from satisfaction in driving consumer behavior, ignoring its existence might positively skew the findings of empirical studies.

Beyond the behavioral consequences of customer satisfaction and dissatisfaction, past studies have stated that customer satisfaction is determined by different factors associated with service quality (Oh, 1999; Parasuraman et al., 1988), and some scholars have also attested to asymmetric relationships between customer satisfaction and its determinants by classifying these determinants into discrete categories based on their asymmetric effects on customer satisfaction (Matzler et al., 2004). Among these studies, a dominant theory being applied is the three-factor theory of customer satisfaction (Füller and Matzler, 2008; Matzler and Renzl, 2007).

\subsection{Three-factor theory}

The three-factor theory can be construed as an extension of two-factor theory of job satisfaction developed by Herzberg et al. (1959) and Matzler and Renzl (2007). The two-factor theory presumes that a set of factors (motivators) produce job satisfaction in the workplace, whereas a separate set of factors (hygiene factors) bring about dissatisfaction. This model of job satisfaction was subsequently adapted to investigate customer satisfaction (Maddox, 1981; Zhang and Von Dran, 2000), thereafter drawing attention to the asymmetric effects imposed by determinants of customer satisfaction. Indeed, PT has lent additional support to the existence of asymmetric relationships between customer satisfaction and its determinants (Kahneman and Tversky, 1979). According to PT, customers are loss-averse; they are more sensitive to and give greater weight to losses than gains (Kahneman and Tversky, 1979). Consequently, a negative performance on an attribute may exert a stronger influence on overall satisfaction than a positive performance on the same attribute (Mittal et al., 1998). For instance, a hotel customer may not be delighted by the availability of a wake-up service but may feel dissatisfied if the service is unavailable.

Consistent with PT, the three-factor theory of customer satisfaction posits that the relationships between overall satisfaction and its determinants may not be symmetric in nature. However, the three-factor theory can be differentiated from the two-factor theory in one key aspect: it classifies the determinants of customer satisfaction into the three categories of basic, performance and excitement factors, namely: 
- Basic factors: Basic factors (dissatisfiers) engender dissatisfaction when absent, but do not lead to satisfaction when present. Customers consider basic factors as the minimum requirements, prerequisites or qualifiers of a service. Meeting customer expectations on basic factors avoids dissatisfaction. Therefore, a low rating on basic factors has a stronger influence on satisfaction than a high rating, implying an asymmetric relationship.

- Excitement factors: Excitement factors (satisfiers) delight customers by inducing customer satisfaction when present, but do not provoke dissatisfaction when absent. Thus, a high rating on excitement factors has a stronger effect on customer satisfaction than a low rating.

- Performance factors: Performance factors (hybrids) have a symmetric and linear influence on customer satisfaction. Specifically, a high performance on performance factors leads to satisfaction whereas a low performance brings about dissatisfaction.

Within extant literature, there is an abundance of evidence alluding to asymmetric relationships between product/service attributes and customer satisfaction, such as in the context of hotel services (Albayrak, 2019; Davras and Caber, 2019; Oh, 2003), sun and sand destinations (Alegre and Garau, 2011), ski resorts (Füller and Matzler, 2008), daily tour service (Albayrak, 2018) and automotive industry (Matzler et al., 2004). In the same vein, a handful of studies have used the three-factor theory to investigate customer satisfaction within hospitality industry. Applying the three-factor theory to comprehend customer satisfaction with travel destinations, Albayrak and Caber (2013) discovered information availability to be a basic factor; health and hygiene, accommodation and shopping to be performance factors; and local transportation to be an excitement factor. In a separate study conducted on the hospitality sector, Albayrak and Caber (2015) revealed that animation, child amenities, cleanliness, food and beverage, personnel, pool and room decoration constitute basic factors, whereas beach access in conjunction with the technical capabilities of hotel rooms are performance factors. Similarly, Matzler et al. (2006) reported that reception, friendliness and service and hotel room are basic factors; wellness area is a performance factor; and hotel restaurant and breakfast are excitement factors. Lai and Hitchcock $(2016,2017)$ have asserted that the categorization of hotel attributes into basic, excitement and performance factors is dependent on hotel characteristics (e.g. boutique, resort and luxury hotels) and customers' previous accommodation experience (e.g. new, repeat and frequent travelers). More recently, Albayrak (2019) found that hotel staff, food and beverage quality, cleanliness of the hotel, outdoor swimming pool, wellness and spa services, children facilities, room technique, timely service and beach are basic factors, whereas hotel ambience is an excitement factor and design of rooms is a performance factor.

Table A1 summarizes related work that testifies to the existence of asymmetric relationships between product/service attributes and overall customer satisfaction in the hospitality sector.

The literature shows that the three-factor theory is an appropriate theory to examine the asymmetric impact of service/product attributes on overall customer satisfaction, and it has also been applied in research in different research contexts (Albayrak and Caber, 2015; Alegre and Garau, 2011; Albayrak, 2018). Thus, the three-factor theory was used as the theoretical framework in this study to examine the asymmetric impact of hotel attributes on customer satisfaction.

\subsection{Deciphering customer satisfaction in the hospitality sector}

There are numerous studies that attest to hotel attributes as determinants of customer satisfaction. According to Parasuraman et al. (1988), customer satisfaction is determined by 
IJCHM 32,5

1718

the performance of different service attributes. In the literature, hotel attributes have been classified into different sub-categories to correspond to various aspects of hotel service (Rhee and Yang, 2015a). To date, prior research has largely derived the range and importance of hotel attributes from surveying customers about their accommodation experiences. Through surveying hotel guests, Qu et al. (2000) advanced six attribute categories covering 33 different hotel services. Choi and Chu (2001) identified seven hotel attributes of customer satisfaction based on survey data collected among international customers to Hong Kong. In their study, staff service quality, room quality and value were found to be the most influential factors delighting customers. Kim and Perdue (2013) suggested to consider the effect of cognitive (brand name, price and service and food quality), affective (entertaining and comfortable feeling) and sensory attributes (overall atmosphere and room quality) on hotel choice. In the research by Hua et al. (2009), service quality was found to be core to the customers in budget hotel market in China.

Prior research has shown that the determinants of customer satisfaction with hotels can be identified through the analysis of online hotel reviews in comparison with a pre-designed questionnaire survey (Jang et al., 2018; Mellinas et al., 2019; Padma and Ahn, 2020; Tian et al., 2016). Li et al. (2013) investigated customer satisfaction in the Chinese hotel industry with online reviews and found that food and beverage management, transportation convenience, value for money and convenience to tourist destinations are important factors considering their importance in determining customer satisfaction; whereas bed, reception services and room size and decoration are also important factors that customers pay attention to, but they are less satisfied with these hotel attributes. Based on online reviews of 149 hotels in Chicago, Jang et al. (2018) have identified 30 most important hotel attributes via text mining, and staff have been found to be the most important attribute with a positive effect on user satisfaction at all the times, and other attributes exert consistent positive/ negative effects with small change of their importance in explaining customer satisfaction. Kim et al. (2016) identified and compared satisfiers and dissatisfiers of full-service and limited-service hotels via content analysis of online hotel reviews on the hotels in New York City and found that staff and their attitude are the most critical factors.

In an attempt to consolidate extant literature on determinants of customer satisfaction in the hospitality sector, Rhee and Yang (2015b) conducted a comprehensive review of past studies and put forth six hotel attribute categories, namely, location, cleanliness, rooms, sleep quality, service and value. Rhee and Yang (2015a) maintained that it might be pragmatic to concentrate on a few focal hotel attributes rather than to overwhelm hotel operators with wide-ranging prescriptions on a multiplicity of attributes. For the same reason, five hotel attributes were selected to explore customers' satisfaction with hospitality services in this study, namely, cleanliness, location, room, service and value. The choice of these five hotel attributes is grounded in both prior research on customer satisfaction and actual practice in the hospitality industry. According to Schuckert et al. (2015), the five hotel attributes capture customers' core considerations when assessing hospitality services. Furthermore, the five hotel attributes also conform to actual practice in that they are synonymous with key dimensions on which hospitality services are being assessed on TripAdvisor, the online review platform where we extracted our data.

Apart from hotel attributes, past studies have also alluded to the impact of culture on customer satisfaction in both offline and online environments. Indeed, prior research has revealed that cultural differences, in the form of geographical location, has a discernible impact on customer satisfaction (Tse and Ho, 2009; Ngai et al., 2007; Rhee and Yang, 2015b). Prior literature have also alluded to the effect of hotel star rating on customer satisfaction (Guo et al., 2016; Jiang et al., 2014; Zhou et al., 2014). For instance, Guo et al. (2016) found 
differences of the most important dimensions of customer satisfaction pertinent to hotels with different star ratings. Thus, in this study, we take both the domestic and international origins of hotel guests and hotel star ratings into consideration in investigating customer satisfaction with hotels. Specifically, reviews written in English are set as international guests and reviews written in Chinese as domestic guests. In line with past studies (Rhee and Yang, 2015b; Yuksel, 2004), we assume that domestic and international guests have separate cultural backgrounds, which may affect their evaluation on the attributes of hotels with different star ratings.

To the best of our knowledge, there is a paucity of studies that shed light on the asymmetric effects of hotel attributes on customers' accommodation experience. Additionally, no previous study has leveraged on data analytics based on online hotel reviews to validate the three-factor theory of customer satisfaction. Furthermore, while prior research has hinted that the star rating of a hotel may alter customers' perception of its attributes (Griffin et al., 1997), an in-depth appreciation of the potential moderating influence of hotel star rating on the asymmetric impact of hotel attributes on customer satisfaction is lacking within extant literature. To this end, we extracted a considerable number of consumer-generated reviews from TripAdvisor to explore the asymmetric effects of five key hotel attributes - cleanliness, location, room, service and value - on customer satisfaction with their service experience. In so doing, this study contributes to extant literature by:

- applying the three-factor theory to disentangle the asymmetric impact of determinants of customer satisfaction within the hospitality sector via data analytics based on online hotel reviews; and

- exploring the moderating influence of hotel star ratings and customer segments (domestic versus international guests) on those determinants.

\section{Methodology}

In this study, we embrace a positivist approach by validating the three-factor theory by analyzing online hotel reviews generated by consumers. In recent years, we have witnessed the increasing popularity of consumer-generated reviews in hospitality industry. Consumergenerated reviews have also been touted to be an indispensable data source for research into customer satisfaction because they are objective and do not succumb to sampling biases that typically accompany traditional survey questionnaires (Schuckert et al., 2015).

\subsection{Sampling and data collection}

Empirical data for this study was extracted from TripAdvisor. TripAdvisor is one of the largest online review sites providing travel-related services in the world. TripAdvisor provides an online rating system for hotel guests to assess the performance of hotel attributes and their overall satisfaction. TripAdvisor data has also been applied in extant research on hospitality in the literature. Following previous research, we applied TripAdvisor data in this study as TripAdvisor provides good data source for this study, such as customer reviews on hotels in different languages from customers in the world. For the purpose of this study, data containing customer reviews and descriptive details of hotels was hence extracted from TripAdvisor. A small program was developed based on hypertext preprocessor language to capture data from the site. We extracted 412,784 consumergenerated reviews from TripAdvisor, ending September 20, 2014, for hotels in five major Chinese cities: Sanya $(N=30,307)$, Beijing $(N=150,616)$, Guangzhou $(N=55,600)$, Shanghai $(N=127,673)$ and Hangzhou $(N=48,588)$. For each review, hotel guests supplied a 
IJCHM 32,5

numerical rating according to their overall satisfaction and also for each of five focal hotel attributes (i.e. cleanliness, location, room, service and value). These ratings were elicited from hotel guests on the basis of a five-point Likert-type scale, ranging from 1 (terrible) to 5 (excellent). Hotel guests also specified the type of travel, including business trip ( $N=165,652)$, couple's trip $(N=26,283)$, family trip $(N=16,984)$, leisure trip $(N=132,527)$, solo trip $(N=9,788)$ and missing value $(N=61,550)$. We also gathered descriptive details for each hotel being reviewed, including its star rating and the city in which the hotel is located.

Among the reviews in our sample, 93.37 per cent $(N=383,639)$ of them are written in either Chinese or English. Compared to the large number of reviews written in Chinese and English, reviews written in other languages are fewer than 10,000. After excluding reviews written in other languages, we divided the remaining reviews in our sample into two groups by detecting whether a review is written in Chinese $(N=287,550)$ or in English $(N=96,089)$.

The remaining 383,639 consumer-generated reviews in our data set cover 10,093 hotels in the five cities. As shown in Table A2, there are more reviews for non-star and five-star hotels. About 30 per cent of reviews are for non-star hotels, which account for nearly 70 per cent of all hotels, whereas 30 per cent of reviews are for five-star hotels even though these five-star hotels only account for 3.5 per cent of all hotels. The concentration of reviews on five-star hotels might be because of the reason that customers are encouraged by the hotels to write reviews based on their accommodation experience.

The average rating of overall satisfaction with the hotels shows that customers are most satisfied with 5-star hotels, followed by 4-4.5 stars hotels, non-star hotels, 2-2.5 stars hotels, 3-3.5 stars hotels and 1-star hotels. Customers are more satisfied with non-star hotels compared to 1 to 3-3.5 stars hotels. This emphasizes the importance of taking hotel star ratings into consideration when examining the determinants of overall customer satisfaction with hotels.

Because non-star hotels have not been graded on the ranking system prevalent in the hospitality sector, which rates hotels based on their facilities, price and service levels (Cser and Ohuchi, 2008), there could be huge variations among them. We thus decided to eliminate non-star hotels from our sample. Likewise, 1-star hotels were excluded from data analysis because of the small number of 1-star hotels (20 hotels) and reviews (148 reviews) in the sample. Our eventual sample consists of 175,577 Chinese reviews and 91,789 English reviews for data analysis. The sample is then spilt into four sub-samples for data analysis according to the four categories of hotel star ratings (i.e. 2-2.5, 3-3.5, 4-0.5 and 5).

\subsection{Data analysis}

We adopted the MySQL and the textcat package in R software to detect the language being used in consumer-generated reviews (Hornik et al., 2013), after which the statistical software of $R$ was used for data analysis to inspect the asymmetric effects of focal hotel attributes on customer satisfaction and dissatisfaction. Regression analysis with dummy variables has been extensively applied in prior research to test asymmetric relationships across diverse contexts (Alegre and Garau, 2011; Füller and Matzler, 2008; Matzler and Renzl, 2007; Oh, 2003). Consistent with extant literature, a set of dummy variables was generated for the current study. Specifically, a rating of 1 or 2 is coded as low performance, a rating 3 or 4 as average performance and a rating of 5 as high performance (Alegre and Garau, 2011). Accordingly, the dummy variables are formulated as low performance $(0,1)$, high performance $(1,0)$ and average performance $(0,0)$. Fixed-effect dummy variable regression was performed to detect asymmetric effects by controlling for discrepancies in city, types of travel and year of rating. The formula for data analysis is given below: 
Overall Rating $=\beta_{0}+\beta_{1}$ (high cleanliness rating) $+\beta_{2}$ (low cleanliness rating)

$$
\begin{aligned}
& \left.\left.+\beta_{3} \text { (high value rating }\right)+\beta_{4} \text { (low value rating }\right)+\beta_{5}(\text { high room rating }) \\
& \left.+\beta_{6}(\text { low room rating })+\beta_{7} \text { (high service rating }\right)+\beta_{8}(\text { low service rating }) \\
& +\beta_{9}(\text { high location rating })+\beta_{10}(\text { low location rating }) \\
& + \text { city }+(\text { type of travel })+\text { year }+\varepsilon
\end{aligned}
$$

An unstandardized coefficient was used to detect asymmetric effects in the regression based on the recommendation of Mikulic and Prebezac (2012). Furthermore, because of the usage of a large amount of data, we subscribed to a conservative approach in defining performance factors by comparing the 95 per cent confidence interval (95 per cent $\mathrm{CI}$ ) of each regression coefficient. The 95 per cent $\mathrm{CI}$ indicates "the range of values that encompass the population or 'true' value" with a given probability of 95 per cent (Nakagawa and Cuthill, 2007, p. 593). Consequently, when the values of the 95 per cent CIs of the high satisfaction level and the low satisfaction level of a hotel attribute overlap, we classify the attribute as a performance factor. Conversely, when no overlap exists between the 95 per cent CIs of the two different levels of an attribute, we regard the related coefficients as being truly detached.

\subsection{Analytical results}

Regression results indicate significant effects of both high and low performance levels of each hotel attribute on customers' overall satisfaction - independent of hotel star rating (Tables A3 and A4). Domestic and international guests differ somewhat with regard to the impact of satisfiers and dissatisfiers, even though a majority of hotel attributes are found to be basic factors across both domestic and international guests. With the exception of cleanliness being a performance factor for hotels with 3-3.5 stars for domestic guests, the five focal hotel attributes constitute basic factors for hotels with 3-5 stars for both domestic and international guests. For hotels with 2-2.5 stars, we uncovered location to be a performance factor, whereas cleanliness, room, service and value constitute basic factors for domestic guests. Conversely, for international guests, room and service act as performance factors whereas cleanliness and value are basic factors and location is an excitement factor.

As depicted in Figure A1, hotel star rating moderates the asymmetric effects of hotel attributes on customers' overall satisfaction. The ensuing research framework exhibits good explanatory power between 61.5 per cent and 67.1 per cent for domestic guests and between 73.4 per cent and 79.5 per cent for international guests.

\section{Discussion and conclusions}

\subsection{Conclusions}

Undoubtedly, guests possess expectations when staying at hotels and are eager to optimize their accommodation experience. The five focal hotel attributes, as espoused in this study, not only aid customers in assessing their accommodation experience but also help in distinguishing the relative importance of each attribute in driving customer satisfaction.

Through our empirical study, we discovered that most hotel attributes act as basic factors, the absence of which leads to customer dissatisfaction. All five focal hotel attributes constitute basic factors for hotels with 4-4.5 and 5 stars for both domestic and international guests. Findings indicate that cleanliness, location, room, service and value should be conceived as essential attributes for luxury hotels (e.g. 4-5 stars hotels) to reduce dissatisfaction among both domestic and international guests. The findings are partly 
IJCHM 32,5

1722

consistent with the prior research work of Padma and Ahn (2020) and Zhou et al. (2014). Based on content analysis of online hotel reviews, Padma and Ahn (2020) found that guests of luxury hotels have specific expectations related to room, cleanliness and service. Zhou et al. (2014) noted that room (such as room size), cleanliness, location (such as close to attraction and accessibility with public transportation) and value (such as room price) are dissatisfiers for customers of luxury hotels (such as 4-5 stars hotels). Such an observation can be attributed to several reasons. As 4-5 stars hotels tend to be more expensive, their guests are bound to have high expectations of the performance of the five focal hotel attributes. If the performance of the five hotel attributes of 4-5 stars hotels falls short of their expectations, both domestic and international guests will be dissatisfied. But at the same time, enhanced performance of the five hotel attributes for 4-5 stars hotels are unlikely to delight domestic and international guests because of their high expectations.

For mid-range hotels (e.g. 3-3.5 stars hotels), the five hotel attributes constitute basic factors for international guests, whereas for domestic guests, location, room, service and value are basic factors, while cleanliness is a performance factor. Our observation of cleanliness as a performance factor for domestic guests might be because of the reason that hotels with higher star ratings (e.g. 4-5 stars hotels) are more competent in maintaining cleanliness as opposed to those with lower star rating (1-3.5 stars hotels). Therefore, even though domestic guests do pay attention to the cleanliness of their accommodations, they possess more reasonable expectations for mid-range hotels such that if the cleanliness of such hotels matches their expectations, they are likely to be satisfied and vice versa.

For economic hotels (e.g. 2-2.5 stars hotels), location is a performance factor whereas cleanliness, room, service and value are basic factors for domestic guests. Conversely, for international guests, room and service are performance factors whereas cleanliness and value are basic factors and location is an excitement factor. Cost savings is paramount for both domestic and international guests who stay at economic hotels. Thus, location is a vital consideration for these customers because they could save from walking rather than taking public transportation. For domestic guests, an economic hotel situated in a good location will satisfy them, whereas a bad location will dissatisfy them. As noted by Ren et al. (2016), location is an important factor determining Chinese customers' satisfaction with budget hotels in China. This might be because domestic guests expect economic hotels to be situated in convenient locations. As for international guests, economic hotels situated in good locations will delight them even though a bad location will not invoke their dissatisfaction. The reason might be that international guests would not mind the bad location of an economic hotel if they have already taken it into consideration in the initial booking. Moreover, because of the lack of dining and entertainment facilities in economic hotels, improved room quality will delight international guests as they need a comfortable room for resting. Because the service quality of economic hotels in China cannot be guaranteed, our findings suggest that international guests will be satisfied if the service quality matches their expectations and dissatisfied otherwise.

Our findings underline the role of cleanliness, location, room, service and value for reducing customer dissatisfaction. For domestic customers, we found cleanliness to be a basic factor except for hotels with 3-3.5 stars hotels. This observation departs from past studies that allude to cleanliness as having the role of both basic and performance factors. While the work of Albayrak and Caber (2015) categorized cleanliness as a basic factor in determining customer satisfaction based on survey data, Ryan and Huimin (2007) regarded cleanliness as a performance factor based on the survey responses from Chinese hotel customers. Our finding on service as a basic factor aligns with the work of Albayrak and Caber (2015) and Deng et al. (2008) with probably the only distinction being that service was 
also found to be a performance factor for international guests staying in economic hotels. Our finding on value as a basic factor of customer satisfaction contradicts the work of Ramanathan and Ramanathan (2011) who equated value with being an excitement factor. In our study, room is a basic factor for both domestic and international guests, except for hotels with 2-2.5 stars for international customers. This is consistent with the work of Albayrak and Caber (2015), Matzler et al. (2006) and Ramanathan and Ramanathan (2011), who classified room as a basic factor. Interestingly, our study illuminates that location can assume the role of basic, performance and excitement factors across distinct customer segments and for hotels with different star ratings. In a way, our findings reinforce the work of Albayrak and Caber (2013) and Füller and Matzler (2008) in that the role of cleanliness, location, room and service as basic, performance and excitement factors differ for both domestic and international guests.

As for the factors that delight domestic guests, room quality appears to be most salient followed by service and value. This finding corroborates the work of Rhee and Yang (2015a), in which they attested to room attribute as being vital to domestic guests, especially with respect to the comfort of the hotel room. Similarly, a good location has a relatively weak effect in delighting guests. But at the same time, location and value have weak impact on guests of luxury hotels with 4-5 stars. Guests of 5-star hotels are less likely to be delighted by cleanliness and service quality when compared to those staying in 2-3.5 stars hotels.

Furthermore, a low performance in room or service quality exerts a strong effect in frustrating guests that is independent of hotel star ratings. Additionally, guests of luxury hotels with 4-5 stars are more adversely affected by low-quality service than guests staying at economic and mid-range hotels with 2-3.5 stars. This impact is especially pronounced for domestic guests staying in 5-star hotels than for those staying in hotels with 4-4.5 stars. For domestic guests staying in 2-2.5 stars hotels, the quality of the room appears to be a stronger dissatisfier than service. Table A3 shows the opposite to hold true. The findings indicate that improving room quality is the most effective way in preventing dissatisfaction among domestic guests staying in 2-2.5 stars hotels. This is followed by the second most critical attribute of service. Improving service quality is crucial for $4-5$ stars hotels. Failing to deliver room and service quality negatively influences the experience of domestic customers.

Our results revealed hotel service to be the most prominent factor delighting international guests followed by room and value. This finding is consistent with prior research of Liu et al. (2017). They compared customer satisfaction with hotels by studying online hotel reviews and found that international hotel guests place greater emphasis on hotel services related to room quality, while the opposite holds true for domestic guests (Liu et al., 2017). For hotels with 2-5 stars, there is an increase in the effect of low-quality service on the dissatisfaction of international guests. Room and service quality constitute performance factors for 2-2.5 stars hotels, pointing to a linear impact of these two hotel attributes on customer satisfaction. Our findings further show that for international customers, economic hotels with bad locations and room quality will lead to dissatisfaction whereas a good location and room quality will delight them. Finally, the poor value of a hotel room often induces dissatisfaction among international guests more than that of a lowquality room.

Magnini et al. (2011) noted that customer satisfaction can be influenced by the origins of the customers or the nature of travel, such as domestic or international hotel guests. Ryan and Huimin (2007) have also stated that customer satisfaction with hotels is affected by hotel star rating. Our findings on the basic, performance and excitement factors for customer satisfaction among domestic and international hotel guests provide further 
IJCHM

32,5

evidence on the impacts of hotel star ratings and cultural origins of customers (such as domestic and international guests) on customer satisfaction with hotels.

\subsection{Implications for theory}

This study contributes to extant literature on four fronts. First, our empirical findings suggest that guests either possess a priori expectations or impose prerequisites on the performance of the five focal hotel attributes and that a majority of these attributes constitute basic factors in driving customer satisfaction. But at the same time, there are a couple of hotel attributes that function as performance or excitement factors for economic and mid-range hotels for certain customer segments. Adhering to the three-factor theory, findings in this study illustrate that the drivers of customer satisfaction - basic, performance and excitement factors - differ across customer segments for hotels with differentiated star ratings. In this sense, this study lends credence to the three-factor theory as a solid theoretical framework for elucidating the asymmetric impacts of product/service attributes on overall customer satisfaction. In addition, we also extend the three-factor theory by demonstrating that basic, performance and excitement factors do not stay invariant and can change their roles depending on customer segments and hotel star ratings. That is, an excitement factor (e.g. location) for an international guest staying in an economic hotel can be a performance factor for domestic guests staying in the same hotel or a basic factor for guests staying in luxury hotels.

Second, this study is among the first to test the three-factor theory in explaining customer satisfaction based on a large amount of online hotel reviews. It is expected that our usage of the large amounts of online hotel review data in data analytics can offer greater precision in pinpointing the asymmetric effects of hotel attributes on customer satisfaction with a high degree of external validity. By quantifying the asymmetric impact of cleanliness, location, room, service and value on customer satisfaction, we obtained insightful findings. In contrast to the work of Albayrak and Caber (2015), who categorized the five hotel attributes as basic factors, we discovered that this only holds true for mid-range and luxury hotels. For economic hotels, certain hotel attributes could become performance (e.g. location, room, and service) or excitement factors (e.g. location) for distinct customer segments (e.g. domestic versus international guests). Through harnessing the large amount of online hotel review data, our findings enrich extant literature on customer satisfaction by building on the three-factor theory to take into consideration determinants of customer satisfaction that vary across customer segments and hotel star ratings.

Third, by delineating between domestic and international guests, we realized that hotel guests value the performance of hotel attributes differently. Domestic guests tend to emphasize room over service quality, whereas international guests treasure the opposite. Variations between domestic and international guests thus highlight the necessity of differentiating them in future studies to yield a more holistic picture of customer satisfaction.

Finally, by analyzing customer ratings alongside hotel star ratings, we witnessed that the effects of high versus low performance of hotel attributes differ across hotels with different star ratings. Findings point to the importance of taking hotel star ratings into account in future research to avoid biasing the results.

\subsection{Implications for practice}

Findings from this study translate into actionable guidelines for hotel operators to make informed decisions regarding service improvement. As revealed in this study, hotel guests, in general, possess a priori expectations of the performance of focal hotel attributes. If the performance of these hotel attributes does not match customers' expectations relative to the 
star rating of a targeted hotel, dissatisfaction will result. Given the stronger impact of lowperformance in comparison to high-performance, we argue that hotel guests can only be delighted when the performance of focal hotel attributes meets the basic expectations of the guests. In other words, satisfying customers' basic expectations is a necessary but insufficient condition for achieving customer satisfaction. Consequently, hotel operators should fulfill the basic requirements for hotel attributes to meet the basic expectations of customers and reduce their dissatisfaction. Furthermore, hotels should be competitive on the performance factors of hotel attributes to increase customer satisfaction and excel on the excitement factors of hotel attributes so as to delight customers. Hotel operators should be cautious when making decisions on delighting customers, as an excitement factor might become a basic factor when customers get acclimatized to being delighted and that positive experiences, which were once a surprise, become mundane (Rust and Oliver, 2000). In other words, improvements in hotel management and investments in hotel facilities may raise guests' expectation of hotel performance such that excitement factors might be downgraded to be basic factors of customer satisfaction.

Furthermore, hotel operators should draw on different attributes when serving domestic versus international guests, as customer satisfaction on a given hotel is influenced by the origins of customers (such as domestic and international customer). For domestic guests, room quality, followed by service quality and value are the key motivators. For international guests, service quality is the most influential motivator followed by room and value. The major factors for dissatisfiers are room and service quality as well as value for domestic guests. As for international guests, cleanliness as well as room, service and value are principal dissatisfiers. In other words, it is imperative to offer high-quality service to both domestic and international guests even though international guests value service quality much more than domestic guests. Nevertheless, in terms of basic requirements, international guests have higher expectations of cleanliness but place less emphasis on room quality, whereas domestic guests possess greater anticipation of room quality with less emphasis on cleanliness. Taken together, these findings yield invaluable insights for hotel operators that target niche market segments. For instance, investments in room renovation are necessary to reduce the dissatisfaction of domestic guests whereas maintaining high standards of cleanliness reduces the dissatisfaction of international guests. Hotel operators should hence pursue separate strategies to enhance satisfaction and reduce dissatisfaction across customer segments.

Last but not least, operators of hotels with different star ratings should tailor their business strategies to fulfill the varying expectations of customers. For instance, 5-star hotels face higher expectations of service quality even though their guests have lower expectations of value and are therefore, less sensitive to price. International guests are less affected by location and room quality when lodging at 3-star hotels as compared to their 5-star counterparts. Nonetheless, operators should foresee a steep increase in expectations of service quality from 3- to 5-star hotels for both domestic and international guests. For operators of economic hotels (e.g. 2-2.5 stars hotels), location is everything, as it can induce satisfaction for both domestic and international guests while minimizing the dissatisfaction of domestic guests.

\subsection{Limitations and future research}

This study has several limitations. First, we compare and contrast the determinants of customer satisfaction for domestic and international guests in the context of Chinese hotels. Though we are confident of the validity of our analytical results, care should still be exercised when generalizing the insights gleaned from this study to other contexts. Second, the study only touches on five focal hotel attributes. For this reason, we cannot claim that the five hotel attributes are exhaustive. Future research can reflect on other hotel attributes

\section{Customer satisfaction with hotels}

1725 
IJCHM 32,5

for which asymmetric effects could exist. Third, in this study, we only scrutinize how the roles of basic, performance and excitement factors differ between domestic and international guests staying in hotels with different star ratings, thereby leaving guest groups from a specific country unexplored. In addition, this study uses overall hotel rating as a proxy for customer satisfaction. It is hence necessary to investigate variations among customer segments having the most common languages on social network sites associated with travel and tourism services (e.g. French, German, Japanese, Russian and Spanish) as well as with the actual review texts via applying other data analysis methods like sentiment analysis. Fourth, Rust and Oliver (2000) stated that customers may become accustomed to being positively surprised and will begin to treat excitement factors that once delight them as normal occurrences. Likewise, Füller and Matzler (2008) called for further research into how long an excitement factor could continue to delight hotel guests. A longitudinal study should thus be conducted to investigate the temporal impact of basic, performance and excitement factors on customer satisfaction. Fifth, this study only applied the data from TripAdvisor until 2014. Future study can consider using recent data and data from different platforms to investigate the impact of hotel attributes on customer satisfaction. Finally, this study does not differentiate between hotel guests according to their demographic characteristics (e.g. gender, age and education). This may serve as an avenue for future research to determine whether moderating influences exist based on the demographic composition of hotel guests.

\section{References}

Albayrak, T. (2018), "Classifying daily tour service attributes by three-factor theory of customer satisfaction", Journal of Quality Assurance in Hospitality and Tourism, Vol. 19 No. 1, pp. 112-125, doi: 10.1080/1528008X.2017.1343169.

Albayrak, T. (2019), "The inclusion of competitor information in the three-factor theory of customer satisfaction”, International Journal of Contemporary Hospitality Management, Vol. 31 No. 4, pp. 1924-1936, doi: 10.1108/IJCHM-03-2018-0239.

Albayrak, T. and Caber, M. (2013), "The symmetric and asymmetric influences of destination attributes on overall visitor satisfaction", Current Issues in Tourism, Vol. 16 No. 2, pp. 149-166, doi: 10.1080/13683500.2012.682978.

Albayrak, T. and Caber, M. (2015), "Prioritisation of the hotel attributes according to their influence on satisfaction: a comparison of two techniques", Tourism Management, Vol. 46, pp. 43-50, doi: 10.1016/j.tourman.2014.06.009.

Alegre, J. and Garau, J. (2011), "The factor structure of tourist satisfaction at sun and sand destinations", Journal of Travel Research, Vol. 50 No. 1, pp. 78-86.

Anderson, R.E. (1973), "Consumer dissatisfaction: the effect of disconfirmed expectancy on perceived product performance", Journal of Marketing Research, Vol. 10 No. 1, pp. 38-44, doi: 10.2307/3149407.

Chen, A., Lu, Y., Gupta, S. and Qi, X. (2014), "Can customer satisfaction and dissatisfaction coexist? An issue of telecommunication service in China”, Journal of Information Technology, Vol. 29 No. 3, pp. 237-252.

Choi, T.Y. and Chu, R. (2001), "Determinants of hotel guests' satisfaction and repeat patronage in the Hong Kong hotel industry", International Journal of Hospitality Management, Vol. 20 No. 3, pp. 277-297, doi: 10.1016/S0278-4319(01)00006-8.

Coghlan, A. (2012), "Facilitating reef tourism management through an innovative importanceperformance analysis method", Tourism Management, Vol. 33 No. 4, pp. 767-775, doi: 10.1016/j. tourman.2011.08.010.

Cser, K. and Ohuchi, A. (2008), "World practices of hotel classification systems", Asia Pacific Journal of Tourism Research, Vol. 13 No. 4, pp. 379-398. 
Davras, Ö. and Caber, M. (2019), "Analysis of hotel services by their symmetric and asymmetric effects on overall customer satisfaction: a comparison of market segments", International Journal of Hospitality Management, Vol. 81, pp. 83-93, doi: 10.1016/j.ijhm.2019.03.003.

Deng, W. (2007), "Using a revised importance-performance analysis approach: the case of Taiwanese hot springs tourism", Tourism Management, Vol. 28 No. 5, pp. 1274-1284, doi: 10.1016/j. tourman.2006.07.010.

Deng, W., Kuo, Y. and Chen, W. (2008), "Revised importance - performance analysis: three-factor theory and benchmarking", The Service Industries Journal, Vol. 28 No. 1, pp. 37-51.

Fuchs, M. and Weiermair, K. (2004), "Destination benchmarking: an indicator-system's potential for exploring guest satisfaction”, Journal of Travel Research, Vol. 42 No. 3, pp. 212-225, doi: 10.1177/ 0047287503258827.

Füller, J. and Matzler, K. (2008), "Customer delight and market segmentation: an application of the three-factor theory of customer satisfaction on life style groups", Tourism Management, Vol. 29 No. 1, pp. 116-126.

Griffin, R.K., Shea, L. and Weaver, P. (1997), "How business travelers discriminate between Mid-Priced and luxury hotels", Journal of Hospitality and Leisure Marketing, Vol. 4 No. 2, pp. 63-75.

Guo, Y., Barnes, S.J., Jia, Q., Choi, T.Y., Chu, R., Kim, D., ... Akula, V. (2016), "Refreshing hotel satisfaction studies by reconfiguring customer review data", International Journal of Hospitality Management, Vol. 10 No. 1, pp. 246-257, doi: 10.1080/15280080802713702.

Herzberg, F., Mausner, B. and Snyderman, B.B. (1959), The Motivation to Work, Wiley, New York, NY.

Hornik, K., Mair, P., Rauch, J., Geiger, W., Buchta, C. and Feinerer, I. (2013), "The textcat package for nGram based text categorization in R", Journal of Statistical Software, Vol. 52 No. 6, pp. 1-17, doi: 10.18637/jss.v052.i06.

Hua, W., Chan, A. and Mao, Z. (2009), "Critical success factors and customer expectation in budget hotel segment - A case study of China", Journal of Quality Assurance in Hospitality and Tourism, Vol. 10 No. 1, pp. 59-74, doi: 10.1080/15280080802713702.

Jang, S., Liu, T., Kang, J.H. and Yang, H. (2018), "Understanding important hotel attributes from the consumer perspective over time", Australasian Marketing Journal (AMJ), Vol. 26 No. 1, pp. 23-30, doi: 10.1016/j.ausmj.2018.02.001.

Jiang, J., Gretzel, U. and Law, R. (2014), "Influence of star rating and ownership structure on brand image of Mainland China hotels", Journal of China Tourism Research, Vol. 10 No. 1, pp. 69-94, doi: 10.1080/19388160.2013.870506.

Kahneman, D. and Tversky, A. (1979), "Prospect theory: an analysis of decision under risk", Econometrica, Vol. 47 No. 2, pp. 263-292.

Kano, N., Seraku, N., Takahashi, F. and Tsuji, S. (1984), "Attractive quality and must-be quality", International Journal of Journal of Japanese Society for Quality Control, Vol. 14 No. 2, pp. $39-48$.

Kim, B., Kim, S. and Heo, C.Y. (2016), "Analysis of satisfiers and dissatisfiers in online hotel reviews on social media”, International Journal of Contemporary Hospitality Management, Vol. 28 No. 9, pp. 1915-1936, doi: 10.1108/IJCHM-04-2015-0177.

Kim, D. and Perdue, R.R. (2013), "The effects of cognitive, affective, and sensory attributes on hotel choice", International Journal of Hospitality Management, Vol. 35, pp. 246-257, doi: 10.1016/j. ijhm.2013.05.012.

Lai, I.K.W. and Hitchcock, M. (2016), "A comparison of service quality attributes for stand-alone and resort-based luxury hotels in Macau: 3-dimensional importance-performance analysis", Tourism Management, Vol. 55 (August), pp. 139-159.

Lai, I.K.W. and Hitchcock, M. (2017), "Sources of satisfaction with luxury hotels for new, repeat, and frequent travelers: a PLS impact-asymmetry analysis", Tourism Management, Vol. 60 (June), pp. 107-129. 
IJCHM

32,5

Li, H., Ye, Q. and Law, R. (2013), "Determinants of customer satisfaction in the hotel industry: an application of online review analysis", Asia Pacific Journal of Tourism Research, Vol. 18 No. 7 , pp. 784-802, doi: 10.1080/10941665.2012.708351.

Liu, Y., Teichert, T., Rossi, M., Li, H. and Hu, F. (2017), "Big data for big insights: investigating language-specific drivers of hotel satisfaction with 412,784 user-generated reviews", Tourism Management, Vol. 59, pp. 554-563, doi: 10.1016/j.tourman.2016.08.012.

Maddox, R.N. (1981), “Two-factor theory and consumer satisfaction: replication and extension”, Journal of Consumer Research, Vol. 8 No. 1, pp. 97-102.

Magnini, V.P., Crotts, J.C. and Zehrer, A. (2011), "Understanding customer delight: an application of travel blog analysis", Journal of Travel Research, Vol. 50 No. 5, pp. 535-545, doi: 10.1177/ 0047287510379162.

Matzler, K., Bailom, F., Hinterhuber, H.H., Renzl, B. and Pichler, J. (2004), "The asymmetric relationship between attribute-level performance and overall customer satisfaction: a reconsideration of the importance-performance analysis", Industrial Marketing Management, Vol. 33 No. 4, pp. 271-277, doi: 10.1016/S0019-8501(03)00055-5.

Matzler, K. and Renzl, B. (2007), "Assessing asymmetric effects in the formation of employee satisfaction”, Tourism Management, Vol. 28 No. 4, pp. 1093-1103.

Matzler, K., Renzl, B. and Rothenberger, S. (2006), "Measuring the relative importance of service dimensions in the formation of price satisfaction and service satisfaction: a case study in the hotel industry", Scandinavian Journal of Hospitality and Tourism, Vol. 6 No. 3, pp. 179-196.

Mellinas, J.P., Nicolau, J.L. and Park, S. (2019), "Inconsistent behavior in online consumer reviews: the effects of hotel attribute ratings on location", Tourism Management, Vol. 71, pp. 421-427, doi: 10.1016/j. tourman.2018.10.034.

Mikulic, J. and Prebezac, D. (2012), "Using dummy regression to explore asymmetric effects in tourist satisfaction: a cautionary note", Tourism Management, Vol. 33 No. 3, pp. 713-716.

Mittal, V., Ross, W.T., Jr. and Baldasare, P.M. (1998), "The asymmetric impact of negative and positive attribute-level performance on overall satisfaction and repurchase intentions", Journal of Marketing, Vol. 62 No. 1, pp. 33-47.

Möhlmann, M. (2015), "Collaborative consumption: determinants of satisfaction and the likelihood of using a sharing economy option again", Journal of Consumer Behavior, Vol. 14, pp. 193-207.

Nakagawa, S. and Cuthill, I.C. (2007), "Effect size, confidence interval and statistical significance: a practical guide for biologists", Biological Reviews, Vol. 82 No. 4, pp. 591-605.

Ngai, E.W.T., Heung, V.C.S., Wong, Y.H. and Chan, F.K.Y. (2007), "Consumer complaint behaviour of Asians and non-Asians about hotel services: an empirical analysis", European Journal of Marketing, Vol. 41 Nos 11/12, pp. 1375-1391, doi: 10.1108/03090560710821224.

Oh, H. (1999), "Service quality, customer satisfaction, and customer value: a holistic perspective", International Journal of Hospitality Management, Vol. 18 No. 1, pp. 67-82.

Oh, H. (2003), "Price fairness and its asymmetric effects on overall price, quality, and value judgments: the case of an upscale hotel", Tourism Management, Vol. 24 No. 4, pp. 387-399.

Oliver, R.L. (1977), "Effect of expectation and disconfirmation on postexposure product evaluations: an alternative interpretation”, Journal of Applied Psychology, Vol. 62 No. 4, pp. 480-486.

Oliver, R.L. (1980), "Cognitive model of the antecedents and consequences of satisfaction decisions", Journal of Marketing Research, Vol. 17 No. 4, pp. 460-469.

Olsen, D. (2010), "One negative customer review online can cost you 30 customers", available at: www. dynamicbusiness.com.au/news/negative-customer-review-online-1562.html

Ou, C.X. and Sia, C.L. (2010), “Consumer trust and distrust: an issue of website design”, International Journal of Human-Computer Studies, Vol. 68 No. 12, pp. 913-934. 
Padma, P. and Ahn, J. (2020), "Guest satisfaction and dissatisfaction in luxury hotels: an application of big data”, International Journal of Hospitality Management, Vol. 84, doi: 10.1016/j.ijhm.2019.102318.

Parasuraman, A., Zeithaml, A.V. and Berry, L.L. (1988), "SERVQUAL: a multiple-item scale for measuring consumer perceptions of service quality”, Journal of Retailing, Vol. 64 No. 1, pp. 12-40.

Qu, H., Ryan, B. and Chu, R. (2000), “The importance of hotel attributes in contributing to travelers' satisfaction in the Hong Kong hotel industry", Journal of Quality Assurance in Hospitality and Tourism, Vol. 1 No. 3, pp. 65-83, doi: 10.1300/J162v01n03_04.

Ramanathan, U. and Ramanathan, R. (2011), "Guests' perceptions on factors influencing customer loyalty: an analysis for UK hotels", International Journal of Contemporary Hospitality Management, Vol. 23 No. 1, pp. 7-25, doi: 10.1108/09596111111101643.

Ren, L., Qiu, H., Wang, P. and Lin, P.M.C. (2016), "Exploring customer experience with budget hotels: dimensionality and satisfaction", International Journal of Hospitality Management, Vol. 52, pp. 13-23, doi: 10.1016/j.ijhm.2015.09.009.

Rhee, H.T. and Yang, S.B. (2015a), "Does hotel attribute importance differ by hotel? Focusing on hotel star-classifications and customers' overall ratings", Computers in Human Behavior, Vol. 50, pp. 576-587, doi: 10.1016/j.chb.2015.02.069.

Rhee, H.T. and Yang, S.B. (2015b), "How does hotel attribute importance vary among different travelers? An exploratory case study based on a conjoint analysis", Electronic Markets, Vol. 25 No. 3, pp. 211-226, doi: 10.1007/s12525-014-0161-y.

Rust, R.T. and Oliver, R.L. (2010), "Should we delight the customer?", Journal of the Academy of Marketing Science, Vol. 28 No. 1, pp. 86-94.

Ryan, C. and Huimin, G. (2007), "Perceptions of Chinese hotels", Cornell Hotel and Restaurant Administration Quarterly, Vol. 48 No. 4, pp. 380-391, doi: 10.1177/0010880407305550.

Schuckert, M., Liu, X. and Law, R. (2015), “A segmentation of online reviews by language groups: how English and non-English speakers rate hotels differently", International Journal of Hospitality Management, Vol. 48, pp. 143-149, doi: 10.1016/j.ijhm.2014.12.007.

Tian, X., Tao, R., He, W. and Akula, V. (2016), "Mining online hotel reviews: a case study from hotels in China", AMCIS 2016: Surfing the IT Innovation Wave - 22nd Americas Conference on Information Systems.

Tse, E.C.Y. and Ho, S.C. (2009), "Service quality in the hotel industry: when cultural contexts matter", Cornell Hospitality Quarterly, Vol. 50 No. 4, pp. 460-474, doi: 10.1177/1938965509338453.

Wickham, H. (2009), ggplot2: Elegant Graphics for Data Analysis, Springer-Verlag, New York, NY.

Yang, Y., Mao, Z. and Tang, J. (2018), "Understanding guest satisfaction with urban hotel location", Journal of Travel Research, Vol. 57 No. 2, pp. 243-259.

Yuksel, A. (2004), "Shopping experience evaluation: a case of domestic and international visitors", Tourism Management, Vol. 25 No. 6, pp. 751-759, doi: 10.1016/j.tourman.2003.09.012.

Zhang, P. and Von Dran, G.M. (2000), "Satisfiers and dissatisfiers: a two-factor model for website design and evaluation", Journal of the American Society for Information Science and Science, Vol. 51 No. 14, pp. 1253-1268.

Zhou, L., Ye, S., Pearce, P.L. and Wu, M.Y. (2014), "Refreshing hotel satisfaction studies by reconfiguring customer review data", International Journal of Hospitality Management, Vol. 38, pp. 1-10, doi: 10.1016/j.jhm.2013.12.004. 
IJCHM

32,5

1730

Albayrak and Hotel

Caber (2015)

Albayrak and

Travel

Caber (2013)

destination

Survey $[N=875]$ Three-factor theory

$\begin{array}{ll}\text { Hotel } & \text { Survey }[N= \\ & 2,404]\end{array}$

Three-factor theory

$\begin{array}{llll}\text { Alegre and } & \begin{array}{l}\text { Sun and } \\ \text { Garau (2011) }\end{array} & \begin{array}{l}\text { Survey }[N= \\ \text { sand } \\ \text { destination }\end{array} & 1,786]\end{array} \quad \begin{aligned} & \text { Three-factor } \\ & \text { theory }\end{aligned}$

Coghlan (2012) Travel Survey $[N=369]$ Importance destination (reef) performance analysis
Table AI.

Review of extant literature on asymmetric relationships between product/ service attributes and overall customer satisfaction
Empirical findings

Basic factor: hotel staff, food and beverage quality, cleanliness of the hotel, outdoor swimming pool, wellness and spa services, children facilities, room technique, timely service and beach

Exciting factor: hotel ambience Performance factor: design of rooms Basic factor: information availability Exciting factor: local transportation Performance factor: health and hygiene, accommodation and shopping Discrepancy among market segments: shopping is a performance factor for the German participants, but a basic factor for the Russian and British participants Asymmetric impact-performance analysis (AIPA)-based on three-factor theory is a more efficient analysis technique than importance-performance analysis (IPA). Basic factor: animation, child amenities, cleanliness, food and beverage, personnel, pool and room decoration Performance factor: beach access and technical capabilities of hotel rooms Basic factor: easy access to info/easy holiday to arrange, accommodation scenery, cleanliness and hygiene, safety, tranquility, and prices in line with budgets Performance factor: nightlife, climate, cultural activities, local life style and local cuisine and beaches

Excitement factor: familiar destination, interesting towns/cities, historic sites, getting to know other tourists and doing sports Basic factor: weather, customer service, quality of the coral, quality of meals, cost of the trip and comfort of the trip

Excitement factor: quality of the equipment, quantity of fish, diversity of the marine life, visibility of the water, comfort of the boat, interactions with passengers, quality of the entertainment, knowledgeable crew, the destination of the trip, quality of the information and availability of souvenirs Performance factor: trip length, and length of time at the reef 


\begin{tabular}{llll}
\hline Authors & Context & Data & Theory \\
\hline Deng (2007) & $\begin{array}{l}\text { Hot spring } \\
\text { tourism }\end{array}$ & Survey $[N=371] \begin{array}{l}\text { Three-factor } \\
\text { theory }\end{array}$
\end{tabular}

Deng et al. (2008) Hotel
Survey [ $N=412]$ Three-factor theory
Fuchs and Travel Survey $[N=$ Weiermair (2004) destination 2,571]

Füller and Matzler (2008)

\section{Ski resort Survey $[N=$} 6,172

Survey $[N=$ $1,555]$

Online customer Importance ratings $[N=$ performance $24,544]$ theory
Empirical findings

Basic factor: responsibility

Excitement factor: empathy and assurance

Performance factor: tangible and reliability

Basic factor: facilities, location, provision of services as promised, customer service, perform service right the first time, readiness and prompt reply to customers, staff's courtesy and friendliness, easy to get staff's attention and help, individual attention for customer, safe environment and equipment, having customers' best interests at heart and understanding the specific needs of customers Performance factor: appealing physical facilities, cleanness of facilities, reasonable price, availability of adequate fire and first aid facilities and instructions, willingness to help customers and personal warm care.

Excitement factor: convenient hotel location, and being able to deal with customers' request

Three-factor Basic factor: booking and reservation, landscape, nostalgic atmosphere, hiking trails, possibilities to relax, customs and traditions, traffic management and management of waiting queues Performance factor: resort information, service adaptability for tourists' families, hospitality of local people and friendliness of tourism employees

Excitement factor: mobility within destination, modernity of the destination, animation, nightlife, all-inclusive cards, access to the internet and tourism services after departure

Three-factor Basic factor: information, price quality theory ratio, slopes, accessibility and well-being Excitement factor: party and kids offerings Roles of the basic, performance and excitement factors differ between different groups

$\begin{array}{lll}\begin{array}{l}\text { Matzler et al. Hotel } \\ \text { (2006) }\end{array} & \begin{array}{l}\text { Survey }[N= \\ 1,555]\end{array} & \begin{array}{l}\text { Three-factor } \\ \text { theory }\end{array} \\ & \begin{array}{l}\text { Online customer } \\ \text { Ramanathan and Hotel }\end{array} & \begin{array}{l}\text { Importance } \\ \text { performance }\end{array} \\ \begin{array}{l}\text { Ramanathan } \\ \text { (2011) }\end{array} & 24,544] & \text { analysis }\end{array}$

Basic factor: friendliness and service, reception and room Performance factor: wellness

Excitement factor: restaurant and breakfast Satisfier: value for money

Dissatisfier: customer service, room quality and quality of food

Performance factor: cleanliness and family friendliness

For leisure guests and the guests of chain hotels, value for money is a dissatisfier

\section{Customer satisfaction with hotels}

1731 


\section{IJCHM}

32,5

\begin{tabular}{llrccc} 
& $\begin{array}{l}\text { Star } \\
\text { rating }\end{array}$ & $\begin{array}{r}\text { No. of } \\
\text { hotels }\end{array}$ & $\begin{array}{c}\text { Percentage (out of all hotels) } \\
(\%)\end{array}$ & $\begin{array}{c}\text { Amount of } \\
\text { reviews }\end{array}$ & $\begin{array}{c}\text { Average rating of overall } \\
\text { satisfaction }\end{array}$ \\
\cline { 2 - 6 } & None & 7,000 & 69.35 & 116,124 & 3.82 \\
Table AII. & 1 & 20 & 0.19 & 149 & 3.72 \\
Number of hotels & $2-2.5$ & 736 & 7.29 & 34,765 & 3.80 \\
with Chinese and & 33.5 & 1,128 & 11.17 & 42,935 & 3.75 \\
English reviews & 4 & 854 & 8.4 & 84,800 & 4.02 \\
& 5 & 355 & 3.5166 & 104,042 & 4.28 \\
\hline
\end{tabular}

\begin{tabular}{|c|c|c|c|c|c|c|c|}
\hline $\begin{array}{l}\text { Star rating (Adj. } \\
\left.R^{2}\right)\end{array}$ & ij. & $\begin{array}{c}\text { High } \\
\text { satisfaction }\end{array}$ & $95 \% \mathrm{CI}$ & $\begin{array}{c}\text { Low } \\
\text { satisfaction }\end{array}$ & $95 \% \mathrm{CI}$ & $\begin{array}{l}\text { Ratio (impact 16ow/ } \\
\text { impact high) }\end{array}$ & $\begin{array}{l}\text { Factor } \\
\text { category }\end{array}$ \\
\hline \multirow{5}{*}{$\begin{array}{l}2-2.5 \text { stars } \\
(67.1 \%)\end{array}$} & Cleanliness & $0.256^{* * *}$ & {$[0.216,0.296]$} & $0.402 * * *$ & {$[-0.474,-0.329]$} & 1.57 & Basic \\
\hline & Location & $0.141^{* * *}$ & {$[0.112,0.170]$} & $0.186^{* * * *}$ & {$[-0.248,-0.124]$} & 1.32 & Performance \\
\hline & Room & $0.471^{* * *}$ & {$[0.430,0.512]$} & $0.761^{* * *}$ & {$[-0.834,-0.688]$} & 1.62 & Basic \\
\hline & Service & $0.247 * * *$ & {$[0.209,0.285]$} & $0.608^{* * * *}$ & {$[-0.669,-0.546]$} & 2.46 & Basic \\
\hline & Value & $0.277^{* * *}$ & {$[0.244,0.309]$} & $0.483^{* * * *}$ & {$[-0.546,-0.419]$} & 1.74 & Basic \\
\hline \multirow{5}{*}{$\begin{array}{l}3-3.5 \text { stars } \\
(66.2 \%)\end{array}$} & Cleanliness & $0.241 * * *$ & {$[0.204,0.277]$} & $0.325^{* * * *}$ & {$[-0.396,-0.254]$} & 1.35 & Performance \\
\hline & Location & $0.123^{* * *}$ & {$[0.096,0.149]$} & $0.213^{* * * *}$ & {$[-0.269,-0.157]$} & 1.73 & Basic \\
\hline & Room & $0.481 * * *$ & {$[0.443,0.519]$} & $0.724 * * *$ & {$[-0.796,-0.653]$} & 1.51 & Basic \\
\hline & Service & $0.270^{* * * *}$ & {$[0.234,0.305]$} & $0.711^{* * * *}$ & {$[-0.765,-0.657]$} & 2.63 & Basic \\
\hline & Value & $0.229 * * *$ & {$[0.197,0.260]$} & $0.521 * * *$ & {$[-0.578,-0.462]$} & 2.28 & Basic \\
\hline \multirow{5}{*}{$\begin{array}{l}4-4.5 \text { stars } \\
(63.7 \%)\end{array}$} & Cleanliness & $0.227 * * *$ & {$[0.204,0.249]$} & $0.374^{* * * *}$ & {$[-0.436,-0.311]$} & 1.65 & Basic \\
\hline & Location & $0.117^{* * *}$ & {$[0.100,0.134]$} & $0.255^{* * * *}$ & {$[-0.301,-0.209]$} & 2.18 & Basic \\
\hline & Room & $0.473^{* * *}$ & {$[0.450,0.495]$} & $0.751^{* * *}$ & {$[-0.813,-0.689]$} & 1.59 & Basic \\
\hline & Service & $0.231 * * *$ & {$[0.209,0.252]$} & $0.773^{* * * *}$ & {$[-0.816,-0.729]$} & 3.35 & Basic \\
\hline & Value & $0.193^{* * * *}$ & {$[0.173,0.214]$} & $0.513 * * *$ & {$[-0.558,-0.468]$} & 2.66 & Basic \\
\hline \multirow{5}{*}{5 stars $(61.5 \%)$} & Cleanliness & $0.204^{* * * *}$ & {$[0.186,0.222]$} & $0.398 * * *$ & {$[-0.472,-0.323]$} & 1.95 & Basic \\
\hline & Location & $0.105^{* * *}$ & {$[0.090,0.119]$} & $0.247 * * *$ & {$[-0.293,-0.201]$} & 2.35 & Basic \\
\hline & Room & $0.490^{* * * *}$ & {$[0.472,0.507]$} & $0.656^{* * *}$ & {$[-0.732,-0.578]$} & 1.34 & Basic \\
\hline & Service & $0.227 * * *$ & {$[0.210,0.243]$} & $0.910 * * *$ & {$[-0.954,-0.865]$} & 4.01 & Basic \\
\hline & Value & $0.132 * * *$ & {$[0.115,0.148]$} & $0.514 * * *$ & {$[-0.555,-0.472]$} & 3.89 & Basic \\
\hline
\end{tabular}

Table AIII.

Results of fixed effect dummy variable regression for domestic guests while controlling for discrepancies in city, types of travel and year of rating 


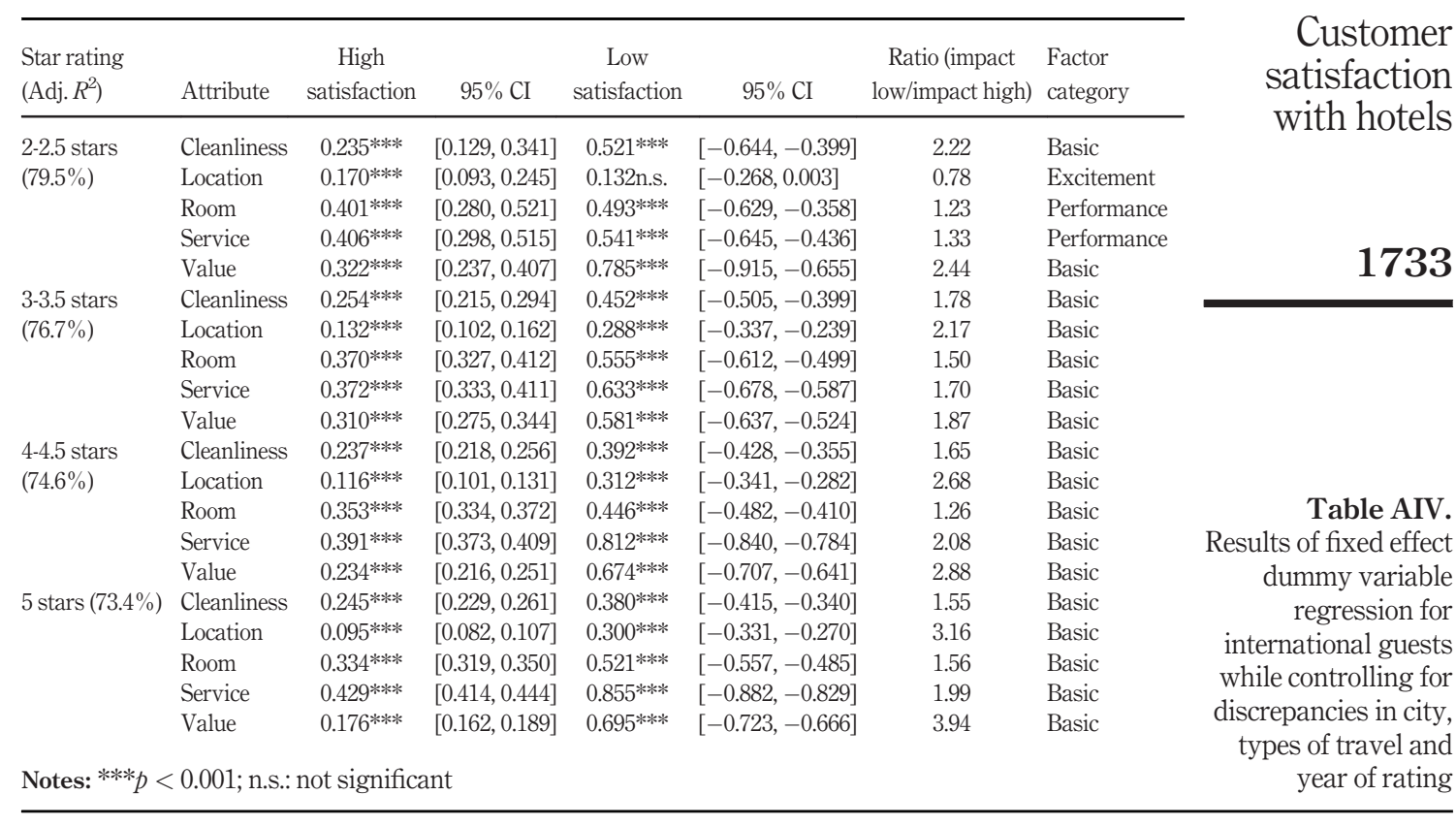


IJCHM

32,5

\section{4}
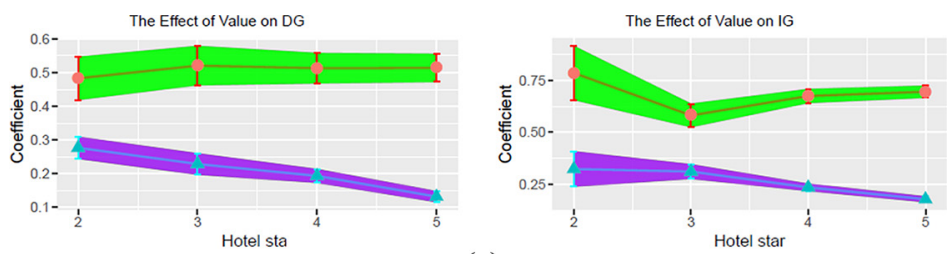

(a)
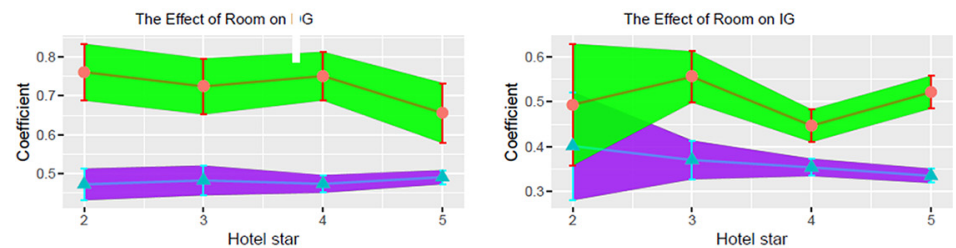

(b)
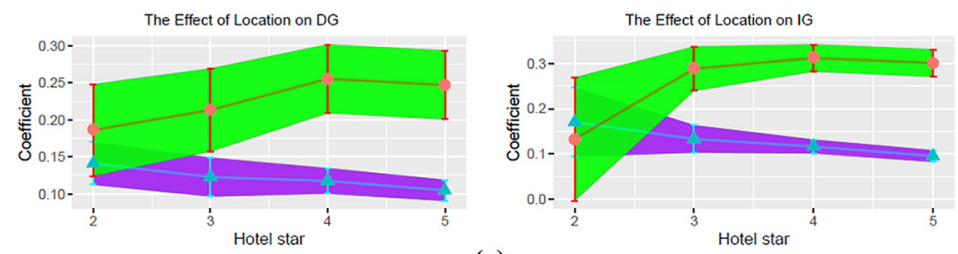

(c)
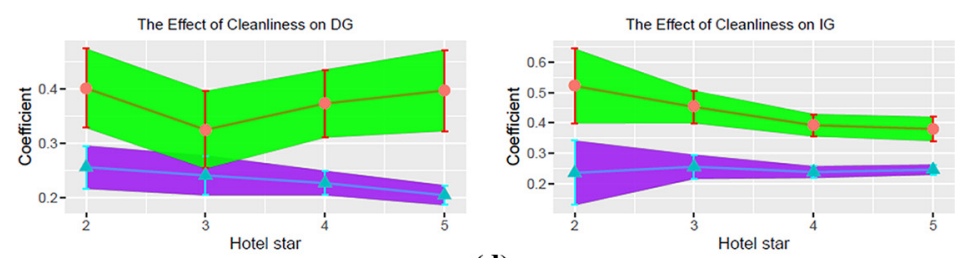

(d)
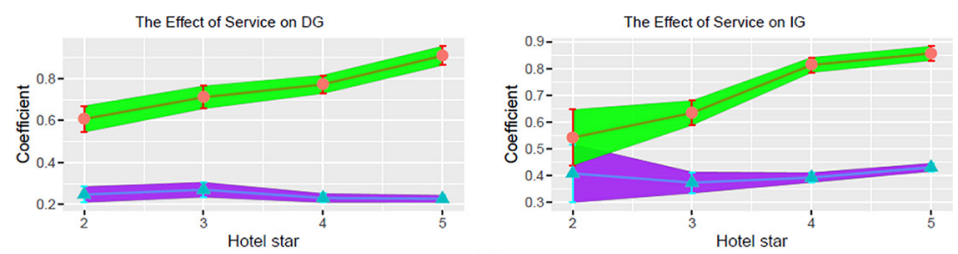

(e)

Note: 1 For each attribute, round dots indicate the absolute value of the coefficients of low satisfaction, triangle dots indicate the coefficients of high satisfaction; green and purple regions highlight the $95 \%$ CIs of low versus high satisfaction levels; values $1-5$ on $\mathrm{X}$-axis represent $0-1,2-2.5,3-$ $3.5,4-4.5$ and 5 star hotels, respectively; the figure is developed via the use of the ggplot2 package (Wickham. 2009) in R. 2. DG: domestic guests; IG: international guests
Figure A1.

Visualizing the moderating influence of hotel star rating on asymmetric effects of hotel attributes on customer satisfaction 


\section{About the authors}

Hongxiu Li is an Assistant Professor at the Department of Information and Knowledge Management, Tampere University, Finland. She received a D Sc (Econ and BA) in Information Systems Science from Turku School of Economics, University of Turku, Finland. Her expertise and research interests cover the areas of information systems use behavior, digital services, social media and big data. Her research has been published in journals such as Information Systems Journal, European Journal of Information Systems, Computers in Human Behavior, Computer and Education, Decision Support Systems, Tourism Management, Information and Management and PLOS ONE. Hongxiu Li is the corresponding author and can be contacted at: hongxiu.li@tuni.fi

Yong Liu is an Assistant Professor of Information Systems at Aalto University School of Business, Finland. He holds a PhD in Business Administration and Economics from Åbo Akademi University, Finland. His research interests cover the areas of big data, electronic commerce, mobile commerce, social media and electronic Word of Mouth. His work has been published in journals, such as ACM Transactions on Computer-Human Interaction, Decision Support Systems (DSS), Information Systems Journal, Information and Management (I\&M), Journal of Advertising Research, Government Information Quarterly (GIQ) and European Journal of Information Systems (EJIS). His research that applied business analytic methods has been published in journals such as Tourism Management (TM) and PLOS ONE. Yong currently serves as an Associate Editor for Internet Research (IntR).

Chee-Wee Tan is a Professor at the Department of Digitalization in Copenhagen Business School (CBS), an Honorary Professor of Business Analytics and Digitalization at the Nottingham University Business School China in the University of Nottingham Ningbo China, an International Visiting Professor at the School of Management in the University of Science and Technology of China, a Senior Research Fellow at the Weizenbaum Institute for the Networked Society and a Visiting Professorial Fellow at the School of Information Systems and Technology Management in University of New South Wales. He received his PhD in Management Information Systems from the University of British Columbia. His research interests focus on design and innovation issues related to digital services. His work has been published in leading peer-reviewed journals such as MIS Quarterly (MISQ), Information Systems Research, Journal of Management Information Systems (JMIS), Journal of the American Society for Information Science and Technology, EJIS and DSS. Apart from his current appointment as a Senior Editor for MISQ, Chee-Wee is currently serving on the editorial boards for Industrial Management and Data Systems, IEEE Transactions on Engineering Management, I\&M, IntR, Journal for the Association of Information Systems, Journal of Computer Information Systems and Journal of Management Analytics. In addition, Chee-Wee has served in various editorial capacities for special issues at Decision Support Systems (DSS), I\&M and JMIS. Finally, he is the Co-director of the joint research center between CBS and the Antai College of Economics and Management in Shanghai Jiao Tong University.

Feng $\mathrm{Hu}$ is an Associate Professor at Xingzhi College at Zhejiang Normal University, China. His research interests cover the areas of text mining, big data social science, electronic commerce and consumer behavior. He has more than 50 publications at international conferences and journals, such as TM, International Journal of Hospitality Management, Journal of Systems and Information Technology, GIQ and Cyberpsychology, Behavior, and Social Networking.

\section{Customer satisfaction with hotels}

For instructions on how to order reprints of this article, please visit our website:

www.emeraldgrouppublishing.com/licensing/reprints.htm

Or contact us for further details: permissions@emeraldinsight.com 